\title{
ИМЕНА СОБСТВЕННЫЕ В РУССКОМ И АНГЛИЙСКОМ ПЕРЕВОДАХ ВЕДЬМАКА А. САПКОВСКОГО
}

\author{
Proper Nouns in Russian and English Translations of "The Witcher" \\ by A. Sapkowski
}

Keywords: Sapkowski, The Witcher, fantasy, translation, proper nouns

Contact: Uniwersytet Śląskiw Katowicach; ziel97@tlen.pl

Имена собственные составляют неотъемлемый компонент каждого языка и независимо от того, как их классифицируем, они всегда содержат культурный оттенок - что может оказаться значительным препятствием для переводчика. В настоящей статье сосредоточимся на анализе имен собственных, которые появились в сборниках рассказов о ведьмаке «Ostatnie życzenie» и «Miecz przeznaczenia» ${ }^{1}$ польского писателя Анджея Сапковского и их переводах на русский («Последнее желание» и «Меч предназначения», пер. Евгения Павловича Вайсброта) и английский языки («The Last Wish», пер. Данусии Сток и «Sword of Destiny», пер. Дэвида Френча).

Эти произведения - представители литературного жанра фэнтези, главной особенностью которого является присутствие магических мотивов и сверхъестественных форм, воспринимаемых как естественная часть представленного мира. Этот фантастический мир регулируется по своим собственным правилам - и они касаются также имен собственных (Guttfeld 2012: 108-109). Обычно герои фэнтези принадлежат к разным общественным слоям и именно поэтому их имена во многом отличаются друг от друга.

При решении лингвокультурологических вопросов переводчики, как правило, применяют одну из двух основных стратегий - т. е. либо доместикацию (одомашнивание), либо форенизацию (отчуждение). В русском и английском переводах произведений, которые являются предметом нашего анализа, преобладает стратегия форенизации. Напомним, что суть этой стратегии состоит

\footnotetext{
${ }^{1}$ Данные сборники рассказов предшествуют составленной из пяти романов «Саге о ведьмаке». Весь цикл книг условно определяется как «Ведьмак».
} 
в том, что переводчик пытается сохранить культурные ценности исходного языка (Spyrka 2011: 251-252). Итак, многие собственные имена в английском тексте остаются без изменений, в русском же - применяется техника транскрипции. Проиллюстрируем это следующими примерами:

Melitele- анг. Melitele, рус. Мелителе;

Stregobor - анг. Stregobor, pyc. Cтрегобор;

Renfri-анг. Renfri, pус. Ренфри;

Istredd - анг. Istredd, pус. Истредд;

Foltest - анг. Foltest, pус. Фольтест;

Pavetta - анг. Pavetta, pyc. Паветma.

Среди обнаруженных нами примеров есть и такие имена, форма которых была частично модифицирована переводчиком с целью адаптировать ее к действующим правилам языка:

Hereward - анг. Hereward, рус. Эревард;

Heribert - анг. Heribert, pус. Эриберт;

Boholt- анг. Boholt, pус. Богольт;

Iola - анг. Iola, pус. Иоля;

Libusze - анг. Libushe, рус. Либуше.

Проблемы с применением транскрипции возникают в случае имен, произношение которых не вполне ясно. Учитывая тот факт, что А. Сапковски владеет многими языками, можно предполагать, что он черпал вдохновение из нескольких из них одновременно. Таким образом, трудно сказать, следует ли произносить данный антропоним согласно принципам польской, немецкой, французской или другой фонетики. Более того, в одном из интервью автор сказал, что, хотя чаще всего он сам придумывал имена, иногда их «подсказала» окружающая среда. Примером таких имен являются Ciri и Bonhart (персонаж, присутствующий в «Саге о ведьмаке»). Имя Ciri взялось из... прайс-листа детских курток, а Bonhart - фамилия клиента компании Сапковского, которую он заметил на счете, лежащем на письменном столе (Sapkowski, Bereś 2005). Однако, он не дает никаких подсказок относительно произношения антропонимов, находящихся в его книгах. На вопрос, как следует их произносить, отвечает следующим образом: «Честно говоря, я не знаю. В одном я уверен: когда речь идет о фамилиях, похожих на французские или немецкие, их следует точно так читать: 
по-французски или по-немецки. Ни в коем случае нельзя читать имена поанглийски. Значит, например, не Реджис, а просто Регис» ${ }^{2}$ (пер. автора - К. 3.).

Таким образом, изобретательность переводчика играет часто главную роль при переводе такого рода антропонимов. Чаще всего эта проблема касается русского варианта, поскольку в большинстве случаев английская орфография позволяет оставить многие названия без изменений, избегая необходимости анализировать их произношение. Итак, попытки переводчиков закончились следующим результатом:

Civril-анг. Civril, рус. Киврил;

Calanthe- анг. Calanthe, рус. Калантэ;

Crach an Craite - анг. Crach an Craite, pyc. Kрах ан Kpaйm;

Cerro - анг. Cerro, pyc. Kepo;

Duny - анг. Duny, рус. Дани;

Ethain- анг. Ethain, рус. Эгайн;

Beau Berrant - анг. Beau Berrant, pyc. Бо Берран;

Geoffrey Monck - анг. Geoffrey Monck, pyc. Джсофррей Монк;

Ivo Mirce - анг. Ivo Mirce, рус. Иво Мирс;

Vereепа - анг. Vereепа, рус. Вереена;

Kudkudak-анг. Coodcoodak, pус. Кудкудак.

В русском переводе обнаруживаем, что переводчик добавляет к данному имени какой-то элемент (например, букву), заменяет его другим или создает свой эквивалент. Так случилось при переводе следующих имен: Ilka стала Иликой, Lenka - Леникой, Niya - Нийями, Yennefer - Йеннифэр. Aspen это Acneм, Hrobarik - Погробарк, а Roedskilde - Ретиильд.

Однако, наиболее интересным вопросом для теоретика перевода являются т. наз. говорящие имена, данные персонажам (или местам) намеренно. Такие имена имеют конкретное значение или относятся к определенным элементам культуры для какой-то цели. Часто имя дает читателю информацию (или намек) о некоторых чертах персонажа, таких как характер, внешность, происхождение и т. д., а название места может быть подсказкой о его жителях, местонахождении, благосостоянии и других. Сложность перевода говорящих имен собственных

2 Режим доступа: https://www.youtube.com/watch?v=rfZkMYZXhLE (2020-03-01); интересующий нас фрагмент начинается в 19 минуте записи. 
заключается в сохранении их смысла. Бывает, что различия между языками делают невозможным перевод данного имени таким образом, чтобы оно охватывало все скрытые аллюзии, предназначенные автором произведения (Зелиньска 2019: 17-18).

Такими именами собственными рассматриваемые нами рассказы изобилуют. Самым популярным из них является, как нам кажется, псевдоним знаменитого трубадура, бабника и эгоцентриста - Jaskier. Русский переводчик использовал эквивалент - Лютик. На английском название этого цвета (buttercup) ничем особым не отличается, в связи с чем переводчики заменили его более «гордым» названием. Переводчик первого сборника сослался на английское название одуванчика - dandelion, но по какой-то причине использовал запись с опечаткой - Dandilion. В рассказах из второго сборника переводчик применил правильную запись, Dandelion.

Аналогичное решение наблюдается в случае прозвища Dzierzba: здесь был применен английский эквивалент Shrike, но в переводе на русский язык к названию птицы сорокопут добавлено окончание, типичное для женского рода. Таким образом возникло название Сорокопутка. Неочевидным же кажется нам стратегия переводчика по отношению к имени Nurzybób. Это польское слово функционирует в качестве синонима для слова lotos. В английской версии использовался эквивалент Nelumbo, но в русской, по неизвестным причинам, Nurzybób стал Щукобобом.

В рассказах появляются имена, построенные путем соединения двух слов. Иногда у них появляется смысловой оттенок, который позволяет делать выводы относительно происхождения - из низких социальных классов. Одним из таких имен является Kozojed. Имя этого крестьянина оригинально вызывает не очень позитивные ассоциации (в частности, если бы в нем поменять одну букву). Сходство этих элементов в русском языке дало возможность оставить его без изменений: Козоед, зато на английском возник Sheepbagger, который также вызывает комическую реакцию. Abrad, которого звали Zadrzykiecka, был переведен как Abrad Jack-up-the-Skirt и Aбрад Юбкодрал. Nosikamyk это Carrypebble и Носикамень, а Myszowór - Mousesack и, просто, Мышиовур. Братьев с именами Pomrów, Paszkot и Dzirżygórka по-английски звали Tinglant, Fodcat и Wieldhill, т. е. эти имена переведены буквально. По-русски же - Слиздяк, Дроздяк и Держигорка. Переводчики позаботились даже о батраке по имени Yolop, которого перевели как Slow и Дурында. В случае бандита с псевдонимом Piętnastka английский язык дал возможность назвать его Fifteen. Русский переводчик решил оставить форму существительного и так создал Десятку. 
Другое прозвище, Oczko, переведено как Little Eуе и Глазок. В случае аптекаря по имени Wawrzynosek, персонажа, появляющегося в рассказе «Ostatnie życzenie», возникло небольшое затруднение, так как в одном фрагменте наблюдаем игру слов, связанную с этим именем. Для того, чтобы ее сохранить, пришлось это имя перевести буквально. Однако, переводчики справились с этой задачей и возник комический эффект, аналогично как в оригинальной версии:

- Do rzeczy, mospanie, do rzeczy. Wrzeszczeliście, że wiedźmin jest niewinny. Jak mam to rozumieć? Że niby Wawrzynosek sam, własnoręcznie obił sobie dupę? Bo jeśli wiedźmin jest niewinny, to inaczej być nie mogło. Chyba że byta to zbiorowa halucynacja.

- Nic mi nie wiadomo o dupach ani halucynacjach - rzekt dumnie Jaskier. Ani o wawrzynowych noskach. (Sapkowski 2014: 299)

'Get to the point, squire, to the point. You yelled that the witcher is innocent. How am I to understand that? That Laurelnose thrashed his own arse with his hands? Because if the witcher's innocent, it couldn't have been otherwise. Unless it was a mass hallucination.'

'I don't know anything about any arses or hallucinations,' said Dandilion proudly. 'Or anything about laurel noses.' (Sapkowski 2012: 252-253)

- К делу, уважсаемые, к делу. Ты кричал, что ведьмак невиновен. Как это понимать? Что, Лавроносик сам себя высек? Потому что ежели ведьмак невиновен, то иначе быть не могло. Разве что коллективная галлюиинация.

- Мне ничего не ведомо ни о... э... высечении, ни о галлючиначиях, гордо проговорил Лютик, - ни о лавровых носиках. (Сапковски 2018: 288)

Большой группой среди имен собственных являются топонимы. Анализируя способы их перевода, можно обнаружить похожие переводческие тенденции, как в случае перевода антропонимов. Большинство названий краев, стран и городов переведено с применением стратегии форенизации. Можно это проиллюстрировать следующими примерами:

Rinde - анг. Rinde, pус. Ринде;

Novigrad - анг. Novigrad, pус. Новиграd;

Blaviken - анг. Blaviken, pус. Блавикен;

Assengard - анг. Assengard, pус. Ассенгард; 
Teтегіa - анг. Teтеria, рус. Темерия;

Skellige - анг. Skellige, pус. Скеллиге;

Cintra - анг. Cintra, pус. Цинтра;

Mahakam - анг. Mahakam, pyc. Махакам.

Похожий прием наблюдаем при названиях рек, которые так же остаются без перевода. Итак, реки Jaruga, Buina, Braa в переводе - это соответственно Jaruga, Buina, Braа и Яруга, Буина, Браа.

Есть и немного модифицированные названия, в которых произошла небольшая коррекция в целях адаптации к правилам языка перевода:

Yspaden - анг. Yspaden, pyc. Испаден;

Aedd Gynvael - анг. Aedd Gynvael, pус. Аэдд Гинваэль;

Maecht - анг. Maecht, pyc. Mexm;

Malleore - анг. Malleore, pус. Маллеора;

Jamurlak - анг. Yamurlak, pyc. Ямурлак;

Guleta - анг. Gulet, pyc. Гулета.

Интересным примером является название города Wyzima. В русском переводе этот город называется аналогично, т. е. Bызима, в то время как на английском языке переводчики предложили две разные версии этого названия, т. е. Wyzim и Vizima.

Топонимы, состоящие из элементов с очевидной смысловой ценностью, обычно подвергаются доместикации. В качестве примеров можно здесь привести следующие названия: Diabli Bród - Devil's Ford и Чертов Брод, Eukomorze Arcsea и Лукоморье, Góry Smocze - Dragon Mountains и Драконьи горы. В случае деревень Górna Posada и Dolna Posada, в русской версии используется аналог Верхний Посад и Нижний Посад, в английской же - переводчик решил оставить второй сегмент без изменений: Upper Posada и Lower Posada (именно тот же перевод использовался также в популярном в последнее время сериале «Тhe Witcher» производства Netflix). Такое переводческое решение может вызывать сомнения, так как, по нашему мнению, следовало здесь применить слово posad, т. е. использовать транслитерацию (поскольку это слово оригинально происходит из русского языка). Удивляет также переводческое решение при переводе названия города Chociebuz, которое является признанным эквивалентом названия города, расположенного в восточной Германии - Cottbus. Русский переводчик 
решил использовать здесь транскрипцию (Хочебуж), хотя в русском языке признанным эквивалентом названия этого города является Котбус. В результате такого решения теряются ассоциации с немецким городом. Похожий прием применил английский переводчик, у которого в результате транскрипции возникло название Hochebuz, хотя в английском языке этот город известен как Cottbus.

К группе топонимов мы относим также названия трактиров, в которых время от времени происходят действия рассказов. Это следующие названия: Pod Tuńczykiem, Pod Zadumanym Smokiem, Pod Lisem, Złoty Dwór, Grot Włóczni и Stary Narakort. Некоторые из них содержат предлог pod с творительным падежом имени существительного. Эта грамматическая форма является типичной для многих польских трактиров и - в настоящее время - гостиниц. В английском переводе этот элемент опущен - название выступает в форме именительного падежа, т. е.: The Tuna Fish, The Pensive Dragon, The Fox. В русском языке переводчик воспользовался аналогичной грамматической формой как автор оригинала, т. е.: Под Альбакором, Под Задумчивым Драконом, за одним исключением - У Лиса. Следующие названия переведены довольно верно: The Golden Court - Золотой Двор, The Spear Blade - Наконечник Пики. Сомнения возникают, однако, в случае названия Stary Narakort. Из «Азбуки» А. Сапковского узнаем, что Narakort является легендарным замком, от которого образовано название данного трактира $^{3}$. Таким образом, нет никаких оснований использовать здесь доместикацию, так как в результате ее применения данное слово теряет свое семантическое наполнение. В английском переводе добавлено слово Inn, которое обозначает трактир или гостиницу (на польском: gospoda, zajazd, karczma, oberża), т. е. применена конкретизация. Помимо прочего, следует отметить, что переведено здесь только имя прилагательное: Old Narakort Inn. Русский переводчик использовал эквивалент Старая Преисподняя. Слово преисподняя можно перевести на польский как zaświaty или piekło, так что выбор переводчика может здесь удивлять.

Таким образом можно прийти к выводу, что при переводе имен собственных в большинстве случаев переводчики сборников рассказов Сапковского применяли стратегию форенизации, оставляя антропонимы и топонимы в оригинальной форме (с использованием транскрипции в русской версии) либо совершая небольшие модификации с целью адаптировать названия к языку перевода. Исключение составили так называемые говорящие имена,

\footnotetext{
${ }^{3}$ Режим доступа: http://web.archive.org/web/20110527131040/http://sapkowski.pl/modules.php?op=modload \&name $=$ Companion \&file $=$ index $\&$ func $=$ alphabet $(2020-03-01)$.
} 
имеющие конкретное значение или относящиеся к определенным элементам культуры. Переводчики пытались одомашнивать их, сохраняя их скрытый смысл - обычно с положительным результатом.

\section{Summary}

The above article oscillates around the topic of translating proper nouns. The issue has been presented on the basis of the exemplification material taken from the collection of short stories preceding the main "The Witcher Saga": "Ostatnie życzenie" and "Miecz przeznaczenia" by Andrzej Sapkowski and their translations to Russian and English languages. The analysis shows the translators' tendency to apply the foreignization strategy, except for significant proper nouns, which in most cases are translated according to the domestication strategy.

\section{Литература}

Зелиньска, К. Интерпретация и перевод имен собственных в литературе фэнтези на примере «Властелина колец» Дж. Р. Р. Толкина. In: Нургали, К. Р., Нургалиевские чтения-VIII: Научное сообщество молодых ученых XXI столетия. Филологические науки. Том I. Нур-Султан: Мастер ПО, 2019, c. $17-21$.

Сапковски, А. Меч предназначения. Пер. Вайсброт Е. П. Москва: Издательство ACT, 2018.

Сапковски, А. Последнее желание. Пер. Вайсброт Е. П. Москва: Издательство ACT, 2018.

Guttfeld, D. Elementy kulturowe $w$ angielsko-polskich przekładach science fiction i fantasy. Toruń: Wydawnictwo Naukowe UMK, 2012.

Sapkowski, A. Miecz przeznaczenia. Warszawa: SuperNowa, 2014.

Sapkowski, A. Ostatnie życzenie. Warszawa: SuperNowa, 2014.

Sapkowski, A. Sword of Destiny. Пep. French D. London: Gollancz, 2016.

Sapkowski, A. The Last Wish. Пep. Stok D. London: Gollancz, 2012.

Spyrka, L. Przekład udomowiony - przekład wyobcowany. Przekład Literatur Stowiańskich. 2011 (2/1), c. 251-265. 


\section{Интернет-источники}

Sapkowski, A., Bereś, S. Historia $i$ fantastyka. 2005. Режим доступа: https://docer.pl/doc/ec0n81 (2020-04-16).

Режим доступа: https://www.youtube.com/watch?v=rfZkMYZXhLE (2020-03-01).

Режим доступа: http://web.archive.org/web/20110527131040/http://sapkowski.pl/ modules.php?op=modload $\&$ name $=$ Companion $\&$ file $=$ index $\&$ func $=$ alphabet (2020-03-01).

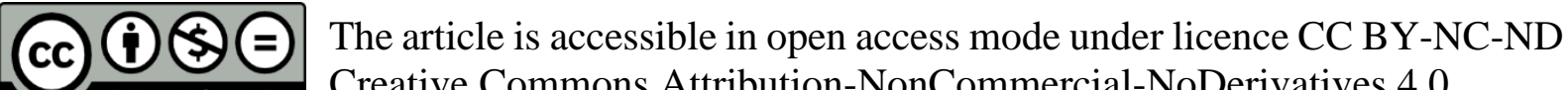
BY NC ND Creative Commons Attribution-NonCommercial-NoDerivatives 4.0 